\title{
The Position and Function of Social Organizations in the Construction of Harmonious Labor Relations
}

\author{
Hong-Zhen LIN \\ School of Management, Wuhan University of Science and Technology Wuhan, China \\ Distinct addresses: 947 He Ping Street, Hubei Wuhan 430081, China \\ linjingziran@126.com
}

Key words: Social Organization, Labor Relation, Harmony

\begin{abstract}
The purpose of this paper is to research the position and function of social organizations in the construction of harmonious labor relations. Using the method of document study and investigation obtained necessary data in order to deeply, correctly understand the problem. The problem of the position and function of social organizations has become more and more important social problem. Effective measures and suggestion to improve the position and function of social organizations in the construction of harmonious labor relations should be put forward based on the analysis of the problems existing in social organizations. The conclusion is that it is important for social organizations to enhance supervision and restriction, provide the necessary social support and energy services for workers.
\end{abstract}

\section{Introduction}

China's economic and social development has gradually entered the period of deepening reform from the transition period, social and economic relations and labor relations have undergone profound changes. Diversified economic and social forms not only bring vitality and vitality into China's economic and social development, but also pose new challenges to the harmony of labor relations. In such a special stage of social development, the construction of harmonious labor relations is not only the requirement of building a harmonious socialist society, but also the guarantee of the strategic goal of China's economic and social development. Discussion on the status and function of social organizations in the construction of harmonious labor relations will play a positive role in overcoming the current problems of labor relations disharmony.

\section{The Connotation of Harmonious Labor Relations}

\section{First, Harmonious Labor Relations Should Be Based On The Legal System.}

Modern society relies on law to regulate human behavior, and law is the basic means to adjust labor relations. Labor relations should be legalized in the aspects of formation, operation, processing and coordination, and the legal principles and legal methods should be taken as the main mode to adjust labor relations [1]. China has promulgated the labor law, labor contract law, labor law, production safety law, Employment Promotion Law, labor dispute mediation and Arbitration Law and a series of labor laws and regulations, this is the basis and guarantee of establishing harmonious labor relations. The two sides of labor relations establish their legal relation of their rights and obligations through signing labor contracts, and regulate and restrict the behaviors of both parties of labor relations in accordance with the laws.

\section{Second, Harmonious Labor Relations Should Be Fair And Just.}

Labor Relations include the formation of the three party consultation mechanism of the labor relationship. The people's governments at all levels of labor administrative department shall, in conjunction with the trade unions and enterprise representatives to establish three party consultation mechanisms on labor relations and jointly participate in the formulation and implementation of labor laws, regulations and policies, to jointly study and resolve major issues of labor relations. formation equal consultation and collective contract system involve the labor rights and interests of workers problem, represented by the union of workers and employers in equal negotiation and 
signing collective contracts to regulate labor relations between the two sides.

Fairness and justice are the foundation of constructing harmonious labor relations. When both sides of the labor relationship sign a labor contract, they should not only follow the laws and regulations, but also do justice and fairness, and determine the rights and obligations of both parties impartially and impartially[2]. Only when the labor contract is signed, the operation of labor process and the distribution of labor achievements can be realized, the enthusiasm of both sides of labor relations can be mobilized, and the creativity of workers can be stimulated.

Third, harmonious labor relations should have an effective mechanism for resolving conflicts and conflicts.

Harmonious labor relations are not without contradiction and conflict, but have a normal channel and means to resolve contradictions and conflicts. Because of the position of both sides of labor relations, position and value orientation have some contradictions is normal [3]. The key is to have a hold and resolve contradiction mechanism. The contradiction of labor relations can be effectively resolved by this mechanism, so as to maintain the dynamic balance of labor relations in the interests of both. Harmonious labor relations should be in benign operation. If the formation and operation process of labor relations in accordance with the law, fully embodies the fairness and justice, labor relations between the two sides truly achieve equal dialogue and open negotiations, democratic consultation, mutual trust and achieve win-win cooperation, mutual reciprocity and mutual benefit, mutual understanding, and through the normal work of effective mechanism to resolve conflicts, to achieve the benign operation of labor relations, the status of labor this relationship is a harmonious labor relations.

\section{The Necessity of Social Organizations to Participate in Labor Relations}

Labor relations are the most basic relationship in the modern world, and also the most basic and important social and economic relationship in modern society [4]. In the work world, industrialization and commercialization of economic activities and market makes the separation of labor and labor data, by way of commodity exchange and organization form of the workers and the labor data together, and to determine a certain contractual relationship between the workers and the labor organization relations of cooperation, so as to realize labor the owner and the owner of production materials, all kinds of social interest, a world of work between modern people's work between the core and basic characteristics[5]. The harmony and progress for security and stability of people's lives, the social and economic relations, labor relations is not only the most basic relations to establish economic ties and stable modern society, individual and society, but also the industrial harmonious society and civilization progress "vane".

The establishment of the reform and opening up and the socialist market economic system, profound changes have taken place in China's economic and social relations, social economic composition, forms of organization, means of employment, interest and distribution diversity, but also by the labor relations based on public ownership, national and personal closely combining the protagonist into a variety of relations the relationship of ownership as the basis, the labor contract is the basic form of the new labor contract relationship. This change in labor relations provides an effective guarantee for the liberation of productive forces, the mobilization of workers' enthusiasm for work, and the promotion of efficient and rapid economic and social development [6]. Meanwhile, great changes have taken place in the interest relations among different stakeholders in the course of labor, such as the differentiation of interest groups, the diversification of interest subjects and the distribution of benefits and the interests of class, and highlight the "strong capital, weak labor" phenomenon, makes the labor relations coordination and conflicts between labor and capital accumulation, labor conflicts become the main reason why we work in the world is not harmonious. 


\section{The Status of Social Organizations in the Construction of Harmonious Labor Relations \\ Firstly, As the Third Force, It Is Essential To Promote Harmony Between Labor And Capital.}

Social organizations, as the third force of harmonious labor relations, have unique advantages and functions beyond the three party relations and the intermediate forces of conflicts of interest. From the sociological point of view, the so-called social organizations refer to the social groups that have specific functions for the purpose of achieving common goals. In the Chinese context, social organizations are mainly composed of social organizations, foundations and private non enterprise units, which constitute an important force for economic and social development together with the government and enterprises [7]. They are independent of the party system, enterprises and institutions, to Philippines profit for the character, in the public or mutual benefit and the way to solve the social problems, coordination of social relations, provide social services play a government and enterprises cannot play the role, is an important social force in the construction of a harmonious society is.

\section{Secondly, It is a Bridge and an Important Assistant between Labor and Enterprise.}

According to the three departments of social governance theory, social organizations or various voluntary associations as the representative of the civil society and civil society, plays a different role in modern social governance. Among them, third social sector solve social problems, coordinate social and economic relations. In the China process of establishing socialist market economy system, the social organization as the representative of the socialist civil society development, solve economic contradictions due to profound changes in the pattern of interest diversification.

\section{The Role of Social Organizations in the Construction of Harmonious Labor Relations}

\section{First of all, The Role of Supervision and Restriction.}

The labor relations system corrects the participation of social organizations in the transformation of government functions. There are different degrees of failure phenomenon and make up the resulting public vacuum assume the role of government transfer to the public service function [7]. At the same time, it can supervise and restrict the disability and dereliction of duty caused by the government's functional departments and administrative officials in pursuit of their own interests, so as to help them perform their duties better.

\section{Secondly, Providing the Necessary Social Support to Balancing Labor Relations.}

In the coordination mechanism of labor relations in modern society, enterprises are always in a strong position in labor relations because of the dominant role of the market in the allocation of labor resources. The labor relations system of social organization intervention for the enterprise to fulfill the social responsibility of workers, balance of labor relations to provide the necessary social support. On the one hand, as citizens of social organization can put forward the corporate social responsibility from advocating social justice and civil rights angle requirements, supervise or assist enterprises to fulfill their social obligations; on the other hand, social organizations can also help enterprises to shape the corporate culture, development of civil behavior, to provide services for enterprises to enhance their ability of social responsibility [8]. In addition, social organizations can also act as mediation into the role in the conflict between labor and capital in the enterprise management concept advocated cooperation, mutual benefit and win-win, through communication and coordination work to resolve the contradictions to avoid conflicts in lose situation.

\section{Thirdly, Providing Energy Services for Workers.}

As the direct party of labor relations, the disadvantaged position in labor relations needs more social attention and protection, and more support and empowerment services are needed. In this regard, the social organizations are independent of the special status of enterprises and government, not 
only can it play an active role, but also bear a major responsibility. First, it can be involved in the labor relations system to transcend the tripartite relationship between the interests of the three parties of the fourth identity as a spokesman for the workers to safeguard their rights and interests, enhance the status of the laborers in labor relations; second, it can also undertake the transfer out of the transformation of government functions in public service responsibility, or commissioned by the government to accept the offer service for the improvement of work and life; third, it also can play the role of educators, help workers set up reasonable benefit view, correct occupation values and a positive working attitude, improve their comprehensive quality and occupation ability, to better adapt to the challenges of working pressure and occupation ${ }^{[9]}$. Fourth, it can also use its own advantages to organize and absorb social resources, provide social support for workers, and improve the social environment for the survival and development of workers.

\section{Conclusion}

The development of social organizations in China is still a new thing. To play its function of harmonious labor relations in the complex social economic relations, between the function and their practical ability, there is still a distance. In recent years. The country explores the social governance structure in the transformation of social management idea, the reform of social management system innovation. Social services have made great efforts to the development of social organization culture and system environment greatly improved. The Development of social organizations has obtained the unprecedented opportunities and good environmental conditions and the social influence and social service the opportunity and ability also greatly enhanced. These changes have created favorable conditions for social organizations to participate in the coordination of labor relations and to create a harmonious industrial society. It is noteworthy that the social work talent development strategy that the party and the state to determine. From the social management and service innovation, social service professional point of view, social organizations carry out capacity building, improve the intervention in the field of labor relations. Labor relations coordination service ability, promote social service organization specialized create more favorable conditions.

To sum up, the development of corporate social work for the government will be promoting the socialist harmonious labor relations. To the enterprise, it is the corporate social responsibility, reduce the enterprise and society, enterprise and staff conflicts, improve enterprise productivity and market economy competitiveness coordinator for employees, and agents. It is to improve their weak position, to realize their own interests and occupation safety and social welfare supporters. Social organizations should realize their vision of pursuing harmonious labor relations and fulfilling their organizational mission in the process of actively introducing and developing social work.

\section{Acknowledgement}

This research was financially supported by Project research of Hubei non-profit organization research center, 2016, The Role and Status of Social Organizations in the Construction of Harmonious Labor Relations. No. HBNPO2016ZD006

This research was financially supported by Project Hubei Province Education Department Foundation: Study on legal guarantee for flexible employment of workers in excess capacity industry in Hubei Province. No. 17Y016

\section{References}

[1] Tu Yongqian, Li Yizhen. Analysis of the Operational Mechanism of Our Social Organizations in the Construction of Harmonious Labor Relations [J]. Journal of Chongqing University of Technology: Social Science Edition, 2016, 30 (12): 69-75.

[2] Wang Xiaoqian. Look At The Positive Role Of Trade Associations And Chambers Of Commerce In Building Harmonious Labor Relations [J]. China Society and Organization, 2015 (1): 30-30. 
[3] Xu Haishan. A Few Trade Union Work of Social Organizations Start Thinking [J]. Chinese Movement, 2017 (1): 30-31.

[4] Liu Hailong. The Three Stages of the Reform of the Dual Management System of Chinese Social Organizations and Their Interpretation [J]. Journal of China Institute of Industrial Relations, 2016 (4): 90-98.

[5] Yang Hongxiao. Study on Cooperative Governance of Social Organizations under the Mode of Chinese Social Governance [J]. Shandong Trade Union Forum, 2016, 22 (6): 94-98.

[6] Li Changjiang, Li Xiaowei. On The Systematic and Overall Reform of Labor Relations Coordination Mechanism in China [J]. Journal of Ningbo University (humanities edition), 2016, 29 (2): 77-83.

[7] Li Qiongying, Zhu. At This Stage of Labor Conflicts in China the Types and Trends and Countermeasures [J] .Zhongzhou Journal, 2015 (12): 72-77.

[8], Zhang long. The Leading Role of Social Organizations in the Employment of Labor Force [J]. essays monthly: Academic Edition, 2015 (7): 48-48.

[9] He Yuan. Social Organization Intervention and Collective Labor Relations Operation. An Exploratory Model of Labor Dispute Mediation [J]. China Human Resources Development, 2015 (15): 93-96. 